\title{
Approach to Quantify Groundwater Recharge Using GIS Based Water Balance Model: A Review
}

\author{
S. S. Rwanga and J. M. Ndambuki
}

\begin{abstract}
Groundwater quantification needs a method which is not only flexible but also reliable in order to accurately quantify its spatial and temporal variability. As groundwater is dynamic and interdisciplinary in nature, an integrated approach of remote sensing (RS) and GIS technique is very useful in various groundwater management studies. Thus, the GIS water balance model (WetSpass) together with remote sensing (RS) can be used to quantify groundwater recharge. This paper discusses the concept of WetSpass in combination with GIS on the quantification of recharge with a view to managing water resources in an integrated framework. The paper presents the simulation procedures and expected output after simulation. Preliminary data are presented from GIS output only.
\end{abstract}

Keywords-GIS, Groundwater, Recharge, Water Balance model, WetSpass.

\section{INTRODUCTION}

Groundwater has emerged to be one of the major sources of potable water for various purposes in both urban and rural areas. Reference [1] reported that groundwater is often the only water resource, which is available round the year. In developing countries and especially in rural areas where the majority of people live, groundwater is frequently the only possible source of good potable water. In arid and semi-arid regions, where water scarcity is almost endemic, groundwater has played a major role in meeting domestic and irrigation demands. This is because; groundwater has the advantage that it is frequently widely available in quantities sufficient to supply the needs of scattered communities.

Identifying of groundwater recharge has shifted from a basic problem to an urgent and fundamental issue in hydrogeologic research for sustainable development of groundwater. It is noted that, quantification of groundwater recharge rate is a prerequisite for efficient and sustainable management of groundwater [2]. This is due to the fact that year after year the global environmental change including climate change, land use change and eventually adaptation processes, thus it is essential to assess the impact of all these changes on groundwater recharge and resources [3].

Over the past decade there has been a significant increase in the development of distributed hydrological models. Several of these models have been labelled "physically- based" having been parameterized in terms of quantities which, at least in

S. S Rwanga is a PhD candidate at Tshwane University of Technology and a Lecturer, Department of Civil Engineering, Vaal University of Technology, Andries Potgieter, private bag X 021, Vanderbijlpark, SE7, 1900 South Africa.

JM Ndambuki is with the Department of Civil Engineering, Tshwane University Technology, Private Bag X680 Pretoria 0001, South Africa. theory, may be physically measurable [4]. Reference [5] argued that such models are merely conceptual models as the physically-based quantities are, in fact, oversimplifications of reality and certainly not measurable with current point scale techniques.

Spatial variation in recharge due to distributed land-use, soil texture, topography, groundwater level, and hydro meteorological conditions are very important parameters which should be accounted for in recharge estimation. As groundwater is dynamic and interdisciplinary in nature, an integrated approach of remote sensing (RS) and GIS technique is very useful in various groundwater management studies [6]. Specifically, a Geographical Information System (G1S) may provide the basic support for many distributed hydrological models.

WetSpass model computes and generates time series of flow hydrographs at selected stations in a recharge areas and maps of spatial outputs. Each map in GIS format is saved at specified time increment, and then used for graphical presentation to see the complete temporal and spatial variation of each variable during a model simulation [7]. All inputs maps for the model are prepared with the aid of ArcGIS. The model can then be simulated on two seasons; summer and winter giving out spatial variations of recharge and runoff as a function of land use and soil type [8].

Research done by [9] found that the performance of WetSpass model depends on the soil type and land use classes; hence lack of relevant land use map may lead to the wrong output which could lead to wrong decisions. However, the model has proven to provide good results provided that accurate and up to date data are used.

The purpose of this paper is to discuss an approach that can be used to quantify groundwater recharge by using GIS based water balance model (WetSpass). The model has been scripted in Python and uses own spatial library Hydrology and Hydraulic Programming Library (H2PL). In this paper, the discussion will be based on the simulation procedures and expected output after simulation. Due to lack of enough data at this stage, the paper will not discuss the output from WetSpass model, however we will give some insight on which output to be expected from the model.

\section{STUDY AREA}

The study area is located $35 \mathrm{~km}$ East of Polokwane and 10 $\mathrm{km}$ North - East of Mankweng (Figure 1) The study area falls within the catchment area of the Turfloop river, which is a tributary of Sand river [10]. The topography of the area consists of two valleys, sloping from east to west and two 
ridges running between the two valleys from east to west. The study area has a summer rainfall climate with moderate to hot temperatures over the year. The temperature ranges from 10.0 degrees minimum to 26.3 degrees Celsius as maximum temperature per annum. Almost the entire area presently relies on groundwater. Groundwater sources in this area are very scarce and declining as a result of over utilization.

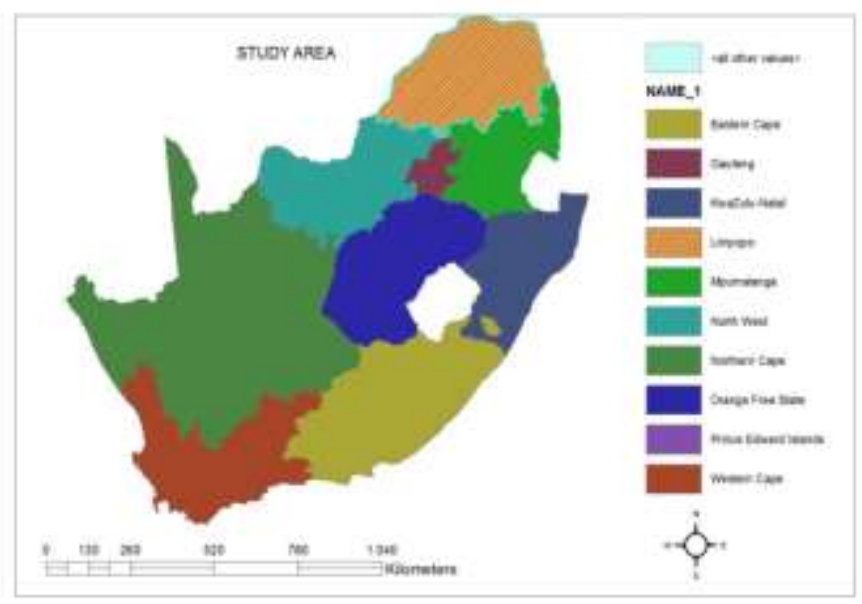

Fig. 1 Map of study area - Limpopo

Currently all the boreholes are not managed scientifically in this area and were not tested to confirm their yields. The regional groundwater harvest potential was not determined in order to calculate the sustainable potential for groundwater abstraction. The absence of this information makes it impossible to develop a better understanding of the factors that influence the behaviour and ultimately the potential of boreholes.

\section{Geology}

The geology map was generated from ArcGIS software. The data was collected from the department of Geoscience, South Africa. The map (Figure 2) shows that, the underlying geology consists of medium-grained, yellowish, laminated sandstone of the Makgabeng Formation of the Waterberg Group. It is also characterized by granite, biotite granite-gneiss, pegmatite, lava and pyroclasts.

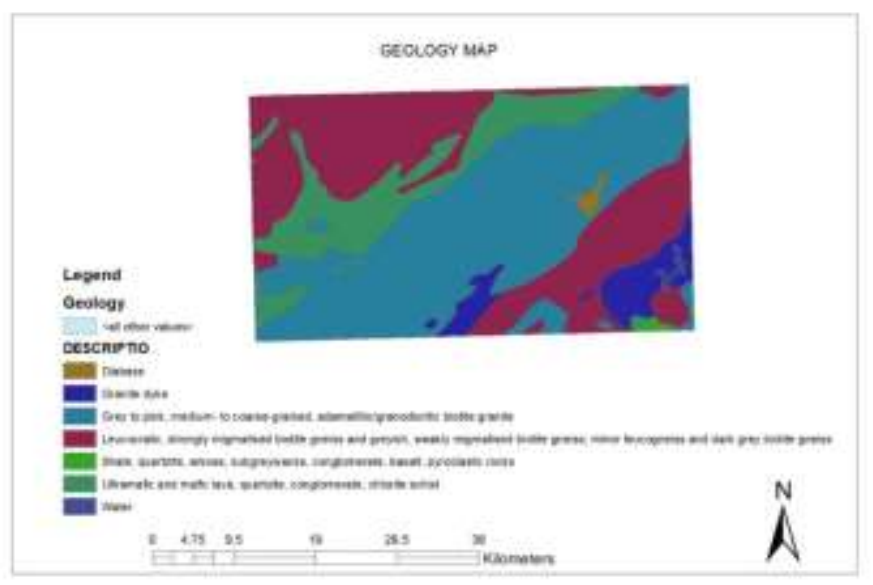

Fig. 2 Geology map of study area

\section{Methodology}

The methodologies of this research consist of four sections: i. Collecting weather data from South Africa Weather services (SAWS) about climate conditions and historical weather data.

ii. Build up land use, rainfall, wind-speed, temperature, and groundwater depth grid maps for summer and winter seasons of years 2004 to 2014

iii. Preparation of soil, slope and topography maps in addition to Land use, Soil, and Runoff Parameters for the years.

iv. Running GIS water balance model (WetSpass).

South Africa ClimateSouth Africa is situated between $22^{\circ} \mathrm{S}$ and $35^{\circ} \mathrm{S}$ in the Southern Hemisphere's subtropical zone. It has a wider variety of climates than most other countries in SubSaharan Africa, and it has lower average temperatures than other countries within this range of latitude, like Australia, because much of the interior of South Africa is at higher elevation.

TABLE I

SOUTH AFrica Climate SEASONS

\begin{tabular}{cccc}
\hline \hline Spring & Summer & Autumn & Winter \\
\hline September & December & March & June \\
October & January & April & July \\
November & February & May & August \\
\hline \hline
\end{tabular}

South Africa has four seasons (Table I) namely, spring (September to November), summer (December to February), autumn (March to May) and winter (June to August).

TABLE II

WEATHER DATA FOR STUDY AREA FROM 2004 - 2014

\begin{tabular}{|c|c|c|c|}
\hline Year & $\begin{array}{c}\text { Average Max } \\
\text { Temperature }(C)\end{array}$ & $\begin{array}{c}\text { Average Minimum } \\
\text { Temperature }\left({ }^{\circ} \mathrm{C}\right)\end{array}$ & $\begin{array}{c}\text { Average Rain } \\
(\mathrm{mm})\end{array}$ \\
\hline 2004 & 25.5 & 12.8 & 39.91 \\
\hline 2005 & 26.1 & 12.8 & 39.37 \\
\hline 2006 & 24.8 & 12.0 & 56.48 \\
\hline 2007 & 25.4 & 11.8 & 35.24 \\
\hline 2008 & 26.0 & 12.5 & 32.17 \\
\hline 2009 & 25.3 & 12.0 & 45.08 \\
\hline 2010 & 25.4 & 11.8 & 39.10 \\
\hline 2011 & 25.6 & 11.5 & 45.14 \\
\hline 2012 & 26.2 & 11.0 & 34.95 \\
\hline 2013 & 25.6 & 10.0 & 53.03 \\
\hline 2014 & 25.0 & 11.4 & 38.04 \\
\hline
\end{tabular}

\begin{tabular}{lcc}
$\begin{array}{l}\text { Average } \\
\text { Wind Speed } \\
(\boldsymbol{m} / \mathbf{s})\end{array}$ & Average Humidity $(\%)$ & $\begin{array}{l}\text { Average Pressure hectopascal } \\
(\boldsymbol{h P a})\end{array}$ \\
2.4 & 68.8 & \\
2.6 & 71.8 & 884.1 \\
2.4 & 74.6 & 883.8 \\
2.6 & 71.0 & 883.8 \\
2.5 & 72.6 & 883.2 \\
2.5 & 75.1 & 883.1 \\
2.3 & 78.6 & 883.5 \\
2.3 & 74.4 & 884.2 \\
2.7 & 67.8 & 882.8 \\
2.6 & 69.9 & 882.9 \\
2.6 & 70.4 & 883.2 \\
\hline
\end{tabular}


The study area climate is considered to be a local steppe climate. There is not much rainfall in Polokwane all year long. The climate is classified as BSk by the Köppen-Geiger system. The area is normally receiving about $389 \mathrm{~mm}$ of rain per year, with most rainfall occurring during summer. The temperature in study area changes throughout the year. (Table II) indicate the data recorded from 2004 to 2014. The maximum temperature was found to be $26.2^{\circ} \mathrm{C}$ at 2012 and the minimum temperate of $10.0^{\circ} \mathrm{C}$ at year 2013 . Average rainfall of $56.48 \mathrm{~mm}$ in 2006. Rainfall is the main source of recharge for groundwater. Thus lack of enough rainfall pose a big challenge of groundwater recharge. Hence there is a need to consider climate change when dealing with quantification of groundwater recharge.

\section{CONCERN ON HYDRO METEOROLOGICAL DATA}

Due to the lack of sufficient spatial hydro meteorological data in regions of Southern Africa, groundwater recharge estimations are based on long-term average rainfall data. In most cases, meteorological data from distant weather/rainfall stations are the only available source of rainfall data for a particular recharge terrain, most probably in a completely different rainfall response area. In this paper, weather data was available for one station only.

\section{MODEL CONCEPT}

The original WetSpass model is a quasi-steady state spatially distributed water balance model scripted in Avenue and used to predict hydrological processes at seasonal and annual time step. With rising popularity of Python programming language in the scientific and research areas, the model has been scripted in Python and using own spatial library Hydrology and Hydraulic Programming Library (H2PL). This newer version of the model has ability to simulate interception from vegetated surfaces, runoff from the landscape, evapotranspiration, soil water balance, and recharge at monthly time step. The user may simulate the model using long-term monthly average values or unique monthly values for many years [11].

Since the model is a distributed one, the water balance computation is performed at a raster cell level. Individual raster water balance is obtained by summing up independent water balances for the vegetated, bare soil, open- water, and impervious fraction of a raster cell. The total water balance of a given area is thus calculated as the summation of the water balance of each raster cell [11].

\section{Interception}

Depending on the type of vegetation, the interception fraction represents a constant percentage of the annual precipitation value. Thus, the fraction decreases with an increase in an annual total rainfall amount (since the vegetation cover is assumed to be constant throughout the simulation period).

\section{Surface runoff}

Surface runoff is calculated in relation to precipitation amount, precipitation intensity, interception and soil infiltration capacity. Initially the potential surface runoff $(\mathrm{S} v$-pot $)$ is calculated as;

$$
S v-p o t=C s v(P-I)
$$

Where, $C$ is a surface runoff coefficient for vegetated infiltration areas, and is a function of vegetation, soil type and slope. In the second step, actual surface runoff is calculated from the $\mathrm{S} v$-pot by considering the differences in precipitation intensities in relation to soil infiltration capacities.

\section{Vegetated area}

The water balance for a vegetated area depends on the average seasonal precipitation (P), interception fraction (I), surface runoff (Sv), actual transpiration (Tv), and groundwater recharge $(\mathrm{Rv})$ all with the unit of $\left[\mathrm{LT}^{-1}\right]$, with the relation given below

$$
P=S v+T v+R v+I
$$

Where $\mathrm{P}$ is the precipitation $(\mathrm{mm}), \mathrm{Sv}$ the surface runoff $(\mathrm{mm}), \mathrm{Tv}$ the actual transpiration $(\mathrm{mm}), \mathrm{Rv}$ the groundwater recharge $(\mathrm{mm})$, and I the interception $(\mathrm{mm})$. The same procedure is used to calculate the water balance for the bare soil, impervious and open-water fractions of a cell. Then the water balance of each grid cell can be calculated by summing up the independent water balances for the different fraction per raster cell. The total actual evapotranspiration (ET) is calculated as the sum of the interception, the transpiration (soil and groundwater) and the evaporation from the bare soil in a grid cell.

The spatially distributed recharge (3) is therefore estimated from the vegetation type, soil type, slope, groundwater depth, and climatic variables of precipitation, potential evapotranspiration, temperature, and wind-speed.

The groundwater recharge, is then calculated as a residual term of the water balance, i.e,

$$
R v=P-S_{v}-E T_{v}-I
$$

ETv is the actual evapotranspiration $\left[\mathrm{LT}^{-1}\right]$ given as the sum of transpiration $\mathrm{Tv}$ and Es (the evaporation from bare soil found in between the vegetation).

All variables and parameters are in digital maps (Table III) and the calculation and derivations are obtained by means of GIS tools and remote sensing. 


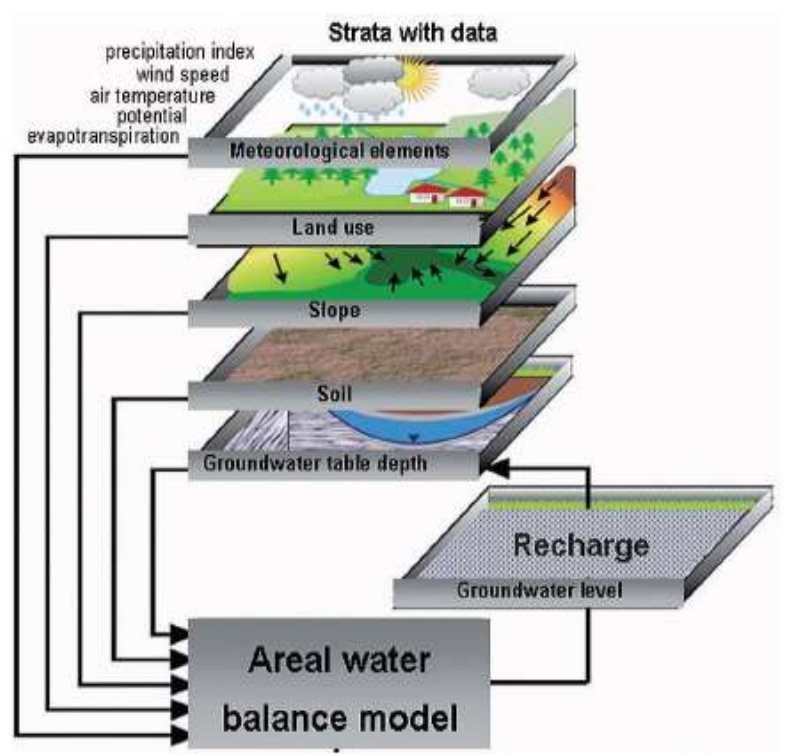

Fig. 3: Schematization and integration of data for a hypothetical cell in the WetSpass water balance model after Batelaan and De Smedt [12]

TABLE III

INPUT FILES FOR WETSPASS MODEL

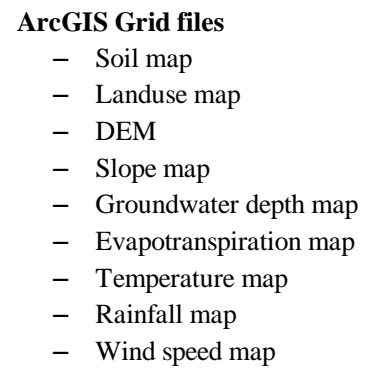

\section{Preparation Of InPUt Data For The Model}

Digital Elevation Map (DEM) and Slope

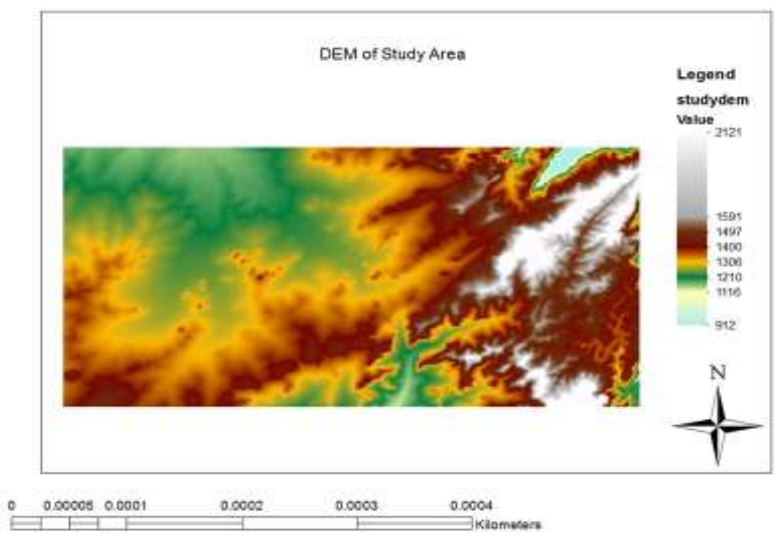

Fig 4: Digital Elevetion Map (DEM) of study area

Based on DEM model (Figure 4), the maximum altitude is $1591 \mathrm{~m}$ and the minimum $912 \mathrm{~m}$. DEM was used to generate a slope map (Figure 5) (as slope measures a rate of change of elevation at a surface location). The slope of the area obtained dictates the actual flow of surface runoff, and hence recharge in the area. The steeper the slope the greater the velocity of the flow will be, and hence the lesser will be the recharge. Moderately steeper slopes in the area indicate that slopes having a lesser gradient in convex plane tend to spread over the land favouring infiltration and thus enhance the groundwater potentiality; the reverse is also true with the steeper slope.

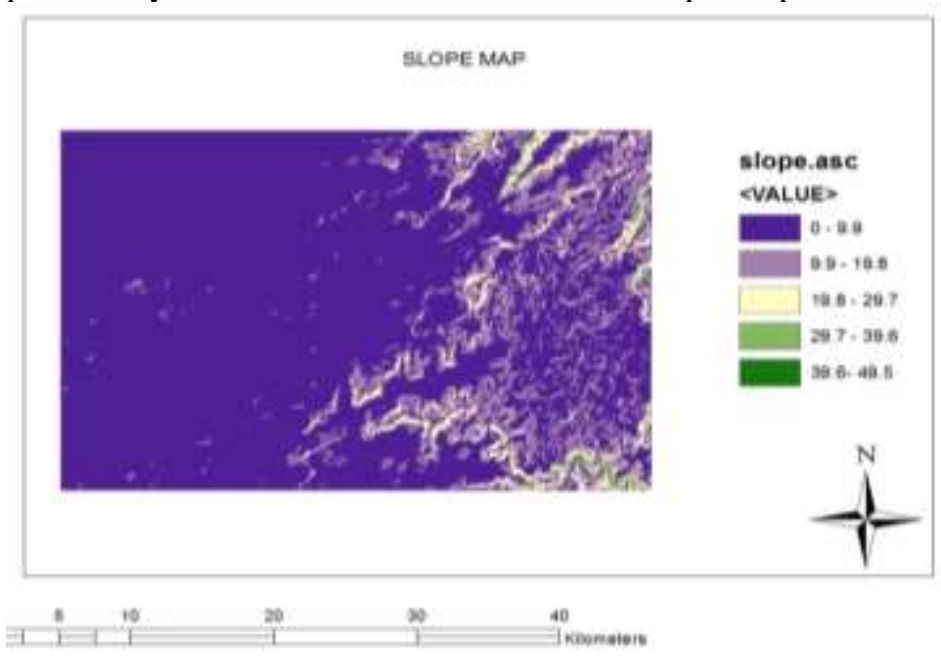

Fig 5: Slope map

From Figure 5, the slope classes includes class 1 (0-9.9), class $2(9-19.8)$, class $3(19.8-29.7)$ and class $4(29.7-39.6)$ and class 5 (39.6 - 49.5). Class 1 is very gentle slope, class 2 is gentle slope, class 3 is moderate, class 4 is steep slope and class 5 is very steep slope.

\section{Landuse Map}

The LULC of the area provides important indications of the extent of groundwater requirements and utilization. From the point of view of land use, dense vegetation is an excellent site for groundwater exploration. The classification was done through supervised classification and the accuracy assessment, through utilization of ground control points in ERDAS IMAGINE (image processing software).

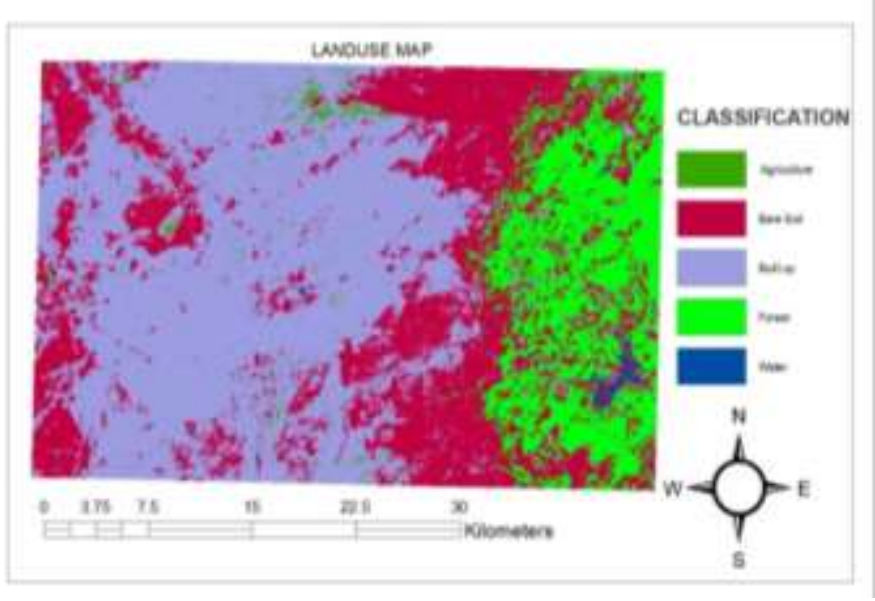

Fig 6: Land use map

Collecting accurate and timely information on land use is important for land use change detection [13] as a basis for 
predicting impact on water resources. In assessing land use, presence, distribution and type of vegetation type play an important role in the estimation of water yield in a catchment. Coniferous forests, for example, consume more water than deciduous forests, while shrubs and grasslands use less water than forests [14]. In this paper, land use classification was based on five classes only namely; agriculture, bare soil, built up, forest and water. This was due to the condition of the model.

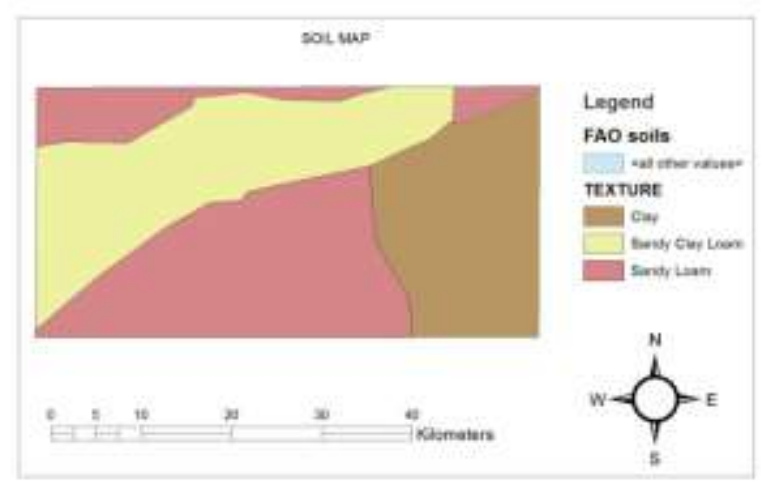

Fig 7: Soil map

The soil grid map for the study area was created from Food and agriculture Organization (FAO) soil map. The study area is composed of clay, sandy clay loam and sandy loam soils as indicated on Figure 7. For successful WetSpass model simulation, the soil lookup table should correspond to entries as indicated on Table III.

The columns in the landuse and soil lookup tables represent the following parameters:

TABLE IV

PARAMETERS NEEDED FOR LAND USE AND SOIL TABLES Landuse.tbl

\begin{tabular}{|c|c|c|c|c|c|c|}
\hline \multirow{2}{*}{$\begin{array}{l}\text { Landuse } \\
\text { No. }\end{array}$} & 1 & 2 & 3 & 4 & 5 & 6 \\
\hline & $\begin{array}{l}\text { Veg } \\
\text { Classes } \\
(\mathrm{No})\end{array}$ & $\begin{array}{l}\text { Imp } \\
\text { Classes } \\
\text { (No) }\end{array}$ & $\begin{array}{l}\text { Veg } \\
\text { Area } \\
\text { (frac) }\end{array}$ & $\begin{array}{l}\text { Bare } \\
\text { Area } \\
\text { (frac) }\end{array}$ & $\begin{array}{l}\text { Imper } \\
\text { Area } \\
\text { (frac) }\end{array}$ & $\begin{array}{l}\text { Open } \\
\text { Water } \\
\text { Area } \\
\text { (frac) }\end{array}$ \\
\hline 7 & 8 & 9 & & 10 & & 11 \\
\hline $\begin{array}{l}\text { Root } \\
\text { Depth }\end{array}$ & LAI & $\begin{array}{l}\text { Min } \\
\text { Ope }\end{array}$ & lata & Inte & & $\begin{array}{l}\text { Veg } \\
\text { height }\end{array}$ \\
\hline
\end{tabular}

\begin{tabular}{l|lllll} 
Soil.tbl & \multicolumn{6}{l}{} \\
\hline Soil No & 1 & 2 & 3 & 4 & 5 \\
\hline & Field & Wilting & $\begin{array}{l}\text { Plant } \\
\text { available } \\
\text { water }\end{array}$ & $\begin{array}{l}\text { Residual } \\
\text { water } \\
\text { content }\end{array}$ & AI \\
& capacity & point & & &
\end{tabular}

\begin{tabular}{l|lll}
\hline 6 & 7 & 8 & 9 \\
\hline $\begin{array}{l}\text { Evapo-De } \\
\text { pth }\end{array}$ & $\begin{array}{l}\text { Tension } \\
\text { height }\end{array}$ & P_fraction_summer & P_Fraction_Winter \\
\hline
\end{tabular}

Table (IV) contains runoff coefficients for unique combination of land use, soil and slope classes.

Parameters, such as land-use, digital elevation map (DEM), slope map and related soil type, are used in the model as ASCII maps. For the land-use type, land cover maps were used, which was based on a Landsat 5 classified image with 50 by $50 \mathrm{~m}$ resolution. In the simulation process groundwater level are used as input to the WetSpass model. This leads to a stable solution for the groundwater level and discharge areas after a few simulations. WetSpass model computes and generates time series of flow hydrographs at selected stations in a recharge area and maps of spatial outputs. Each map in GIS format is saved at specified time increment, and then used for graphical presentation to see the complete temporal and spatial variation of each variables during a model simulation.

\section{SIMULATION OF THE MODEL}

The model has ability to simulate interception from vegetated surfaces, runoff from the landscape, evapotranspiration, soil water balance, and recharge at seasonal time step. The user may simulate the model using long-term seasonal average values or unique seasonal values for many years.

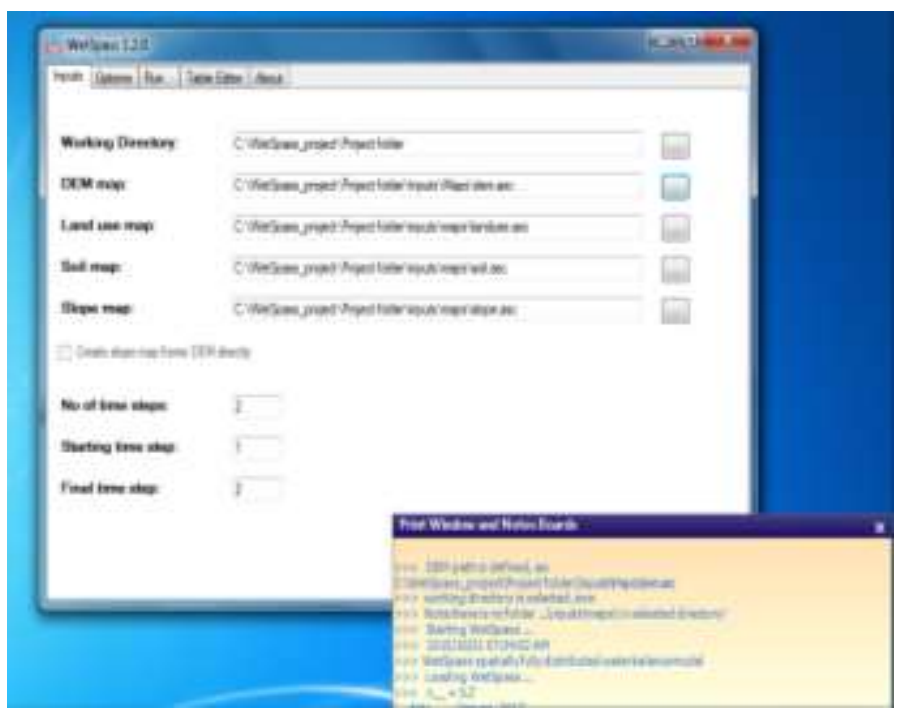

Fig 8: Graphical User Interface of the WetSpass model

\section{Procedures}

\section{Step 1: Assign Files}

User needs to assign path of the working directory till the project folder, only (Figure 8). Once, the working directory is assigned, rest of the map paths are automatically picked up in DEM. After assigning the files, the option tabs follows which facilitate the user to assign prefix to the ascii files (Figure 9). User can opt to load default file names by pressing the button load defaults.After that the user have to identify the output directory where all the maps will be stored ( Figure 10). Once, the paths to the maps have been assigned, Run tab can be used to run the model (Figure 11). Pressing the RUN button will start model simulations, and progress bar will be indicated on time bar of the windows OS. 


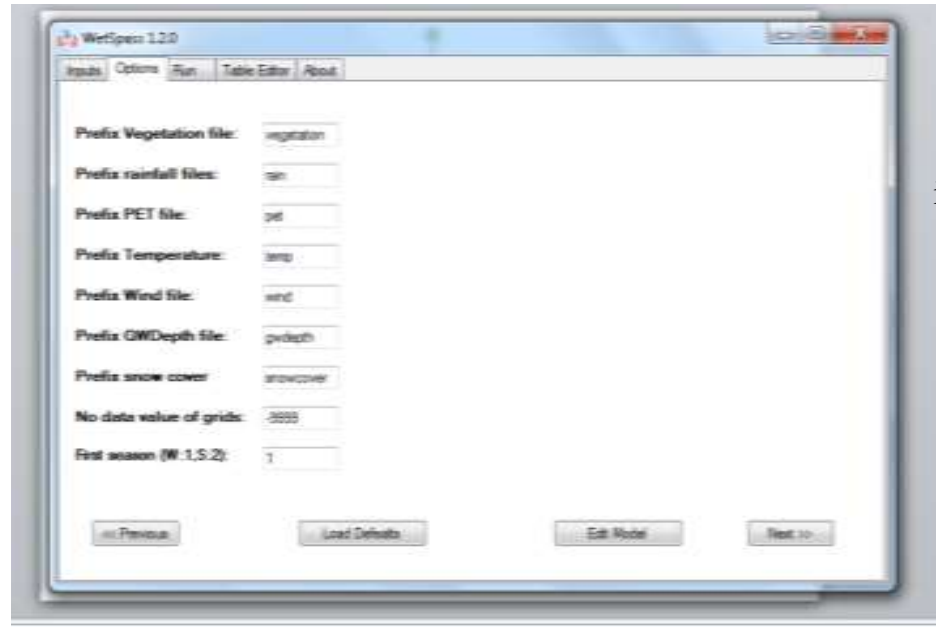

Fig. 9: Option tabs defaults

\section{Step 2: Identify Output Files}

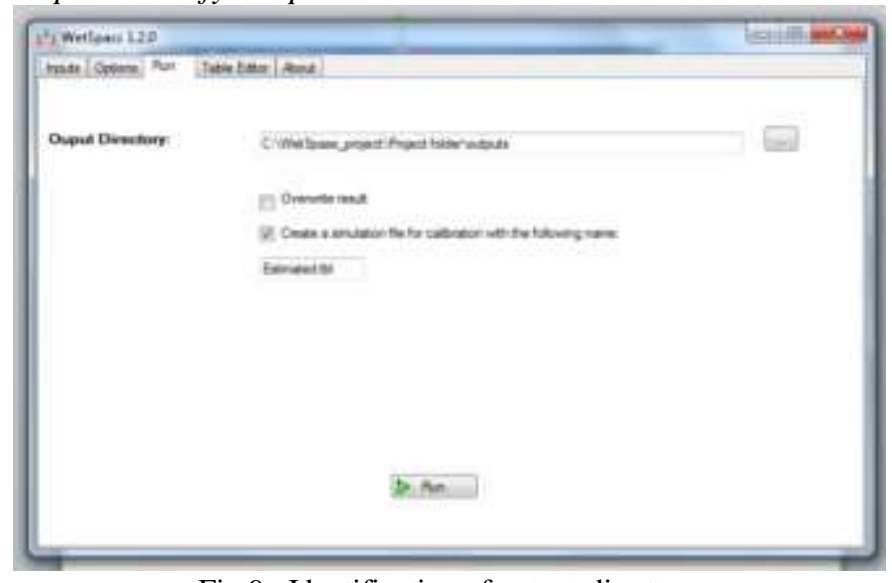

Fig 9: Identification of output directory

Step 3: Run the Model

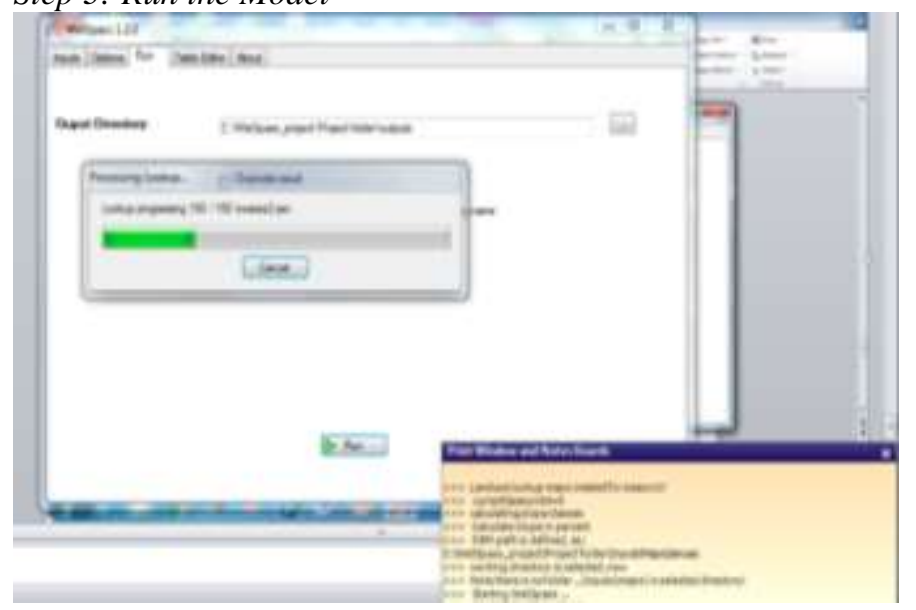

Fig 10: Run tab

After the simulation, WetSpass model output grids include projected results for: i. Surface Runoff by Using Runoff Coefficients. These Coefficients Are Based On Vegetation Type, Soil Texture Class And Slope Value.

ii. Evapotranspiration

iii. Interception Transpiration

iv. Soil Evaporation

v. Recharge And

vi. The Error Percentage In Water Balance

\begin{tabular}{|c|c|c|c|c|}
\hline $\begin{array}{l}\text { Totalin } \\
\text { tercepti } \\
\text { on }\end{array}$ & $\begin{array}{l}\text { Map giving } \\
\text { interception } \\
\text { from the } \\
\text { vegetated } \\
\text { surface }\end{array}$ & $\begin{array}{l}\text { Total } \\
\text { actual } \\
\text { transpir } \\
\text { ation }\end{array}$ & \multicolumn{2}{|c|}{$\begin{array}{l}\text { Map giving actual } \\
\text { transpiration } \\
\text { vegetated surface of grid }\end{array}$} \\
\hline $\begin{array}{l}\text { Bareru } \\
\text { noff }\end{array}$ & $\begin{array}{l}\text { Map giving } \\
\text { runoff due to } \\
\text { bare surface of } \\
\text { each grid }\end{array}$ & $\begin{array}{l}\text { Total } \\
\text { gwevap } \\
\text { oration }\end{array}$ & \multicolumn{2}{|c|}{$\begin{array}{l}\text { Map giving total } \\
\text { evaporation contributed by } \\
\text { groundwater }\end{array}$} \\
\hline $\begin{array}{l}\text { Imperr } \\
\text { unoff }\end{array}$ & $\begin{array}{l}\text { Map giving } \\
\text { runoff due to } \\
\text { impervious } \\
\text { surface of each } \\
\text { grid }\end{array}$ & $\begin{array}{l}\text { Total } \\
\text { gwtrans } \\
\text { piration }\end{array}$ & \multicolumn{2}{|c|}{$\begin{array}{l}\text { Map giving total } \\
\text { transpiration contributed by } \\
\text { groundwater }\end{array}$} \\
\hline $\begin{array}{l}\text { Vegrun } \\
\text { off }\end{array}$ & $\begin{array}{l}\text { Map giving runoff } \\
\text { due to vegetated } \\
\text { surface of each grid }\end{array}$ & \multicolumn{2}{|c|}{$\begin{array}{l}\text { Total } \\
\text { imperevapo } \\
\text { ration }\end{array}$} & $\begin{array}{lr}\text { Map } & \text { giving } \\
\text { evaporation } & \text { from } \\
\text { impervious } & \text { surface } \\
\text { of the grid } & \end{array}$ \\
\hline $\begin{array}{l}\text { OWrun } \\
\text { off }\end{array}$ & $\begin{array}{l}\text { Map giving runoff } \\
\text { due to open water } \\
\text { surface of each grid }\end{array}$ & \multicolumn{2}{|c|}{$\begin{array}{l}\text { Total OW } \\
\text { evaporation }\end{array}$} & $\begin{array}{lr}\text { Map } & \text { giving } \\
\text { evaporation } & \text { from } \\
\text { open water surface of } \\
\text { grid }\end{array}$ \\
\hline $\begin{array}{l}\text { Total } \\
\text { evapotr } \\
\text { anspirat } \\
\text { ion }\end{array}$ & $\begin{array}{l}\text { Map giving total } \\
\text { runoff in each grid }\end{array}$ & \multirow{3}{*}{\multicolumn{2}{|c|}{$\begin{array}{l}\text { Total } \\
\text { evapotransp } \\
\text { iration }\end{array}$}} & $\begin{array}{l}\text { Map giving total } \\
\text { Evapotranspiration } \\
\text { from each grid }\end{array}$ \\
\hline $\begin{array}{l}\text { Soil } \\
\text { water } \\
\text { storage }\end{array}$ & $\begin{array}{l}\text { Soil water storage } \\
\text { after } \\
\text { computation }\end{array}$ & & & \\
\hline $\begin{array}{l}\text { Rechar } \\
\text { ge }\end{array}$ & $\begin{array}{l}\text { Recharge } \\
\text { map }\end{array}$ & & & \\
\hline
\end{tabular}

Table V shows the output folder contains a folder named Lookup, which hold all the maps generated for various parameter using land use and soil lookup tables. These maps are produced as a result of pre-processing after simulation starts. The maps can thereof be presented using GIS to see the complete temporal and spatial variation of each variable during a model simulation.

\section{CONCLUSION}

The mapping of groundwater resources has been increasingly implemented in recent years because of the increased demand for water. GIS and WetSpass model is a tool that can simulate accurately the spatial and temporally distribution of long-term average recharge. It has ability to simulate interception from vegetated surfaces, runoff from the landscape, evapotranspiration, soil water balance, and recharge at monthly time step. The user may simulate the 
model using long-term monthly average values or unique monthly values for many years. The estimated distributed recharge through

WetSpass can, therefore, be used in regional steady-state groundwater models and, hence, decrease the uncertainty estimation of groundwater recharge. The model gives various hydrological outputs on yearly and seasonal (summer and winter) basis. Moreover the results from the model can be analysed in various ways. The analysis can include; summer and winter output difference, analysis of spatial variations of recharge runoff as a function of land use and soil type and analysis of evapotranspiration and recharge.

The model has successful applied to different parties of the world to account for groundwater recharge estimates. Previous applications showed that, the model can be used to quantify both groundwater recharge and discharge.

\section{REFERENCES}

[1] H.Wang, L. kgotlhang and W. Kinzelbach, Using remote sensing data to model groundwater recharge potential in Kanye region, Botswana. The International Archives of the Photogrammetry, Remote Sensing and Spatial Information Sciences, 2008 Vol. 37. Part B8.

[2] O Batelaan, and F De Smedt "GIS-based recharge estimation by coupling surface-subsurface water balances" Journal of Hydrology, 337(3-4), 337-355, DOI: 10.1016/J.JHYDROL.2007.02.001" 2007

[3] S. Stoll "On the impact of climate change on Groundwater resources" $\mathrm{PhD}$ Thesis, DISS. ETH NO. 20443, Eth Zurich, 2012.

[4] O. Batelaan and T. Kuntohadi "Development and application of a groundwater model for the Upper Biebrza River Basin" Ann. Warsaw Agriculture. University, Land Reclamation, 2002, volume 33, pp. 57-69.

[5] K. Beve " Changing ideas in hydrology. The case of physically based models" Journal of. Hydrology, 1989, volume. 105, pp. 157-172 https://doi.org/10.1016/0022-1694(89)90101-7

[6] A Chowdhury, MK Jha, and VM Chowdary, "Delineation of groundwater recharge zones and identification of artificial recharge sites in West Medinipur district, West Bengal, using RS, GIS and MCDM techniques" Environ Earth Science 59:1209-1222, 2010. https://doi.org/10.1007/s12665-009-0110-9

[7] S Rwanga, A Review on Groundwater Recharge Estimation Using Wetspass Model. International Conference on Civil and Environmental Engineering (Cee'2013) Nov. 27-28, 2013 Johannesburg (South Africa)

[8] M. AL Kuisi AND A. EL-Naqa, GIS Based Spatial Groundwater Recharge Estimation In The Jafr Basin, JORDAN - Application of WETSPASS models for arid regions. REVISTA MEXICANA DE CIENCIAS GEOLÓGICAS, V. 30, NÚM. 1, 2013, P. 96-109.

[9] Abu-Saleem, Y. AL-ZU'BI, O. RIMAWI, J. AL-ZU'BI AND N.A. AL-BALQA, estimation of water balance components in the Hasa basin with GIS based WETSPASS model. Journal of Agronomy, 2010, Volume 9, Issue 3, Pp. 119 -125

[10] Müller, A.B. and Nkuna, E. (2009). Sebayeng/Dikgale Regional Water Supply Scheme The Polokwane Municipality

[11] K. Abdollahi, I. Bashir and O. Batelaa "WetSpass graphical user interface" 2012

[12] O. Batelaan and F. De Smedt, WetSpass: a flexible, GIS based, distributed recharge methodology for regional groundwater modelling", Impact of Human Activity on Groundwater Dynamics, IAHS Publ. No. 269, 2001

[13] C Giri, Z Zhu, and B Reed " A comparative analysis of the Global Land Cover 2000 and MODIS land cover data sets"Remote Sens. Environ. 94 123-132, 2005 https://doi.org/10.1016/j.rse.2004.09.005

[14] JM Bosch and JD Hewlett "A review of catchment experiments to determine the effect of vegetation changes on water yield and evapotranspiration" J. Hydrol. 55 (1-4) 3-23, 1982

https://doi.org/10.1016/0022-1694(82)90117-2 